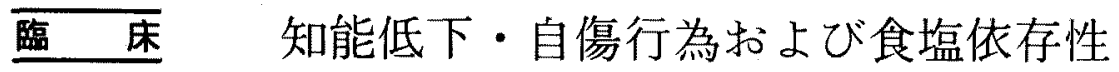

高血圧を伴つた尿酸排泄障害型痛風患者の 1 例

\begin{tabular}{|c|c|c|c|c|}
\hline \multicolumn{5}{|c|}{ 筑波大学臨床医学系内科 } \\
\hline 川 & 紘一○ & 藤田 敏郎 & 板倉 & 光夫 \\
\hline & 哲 & 小出 義信 & 久貝 & 信夫 \\
\hline & 哲 & 山下亀次郎 & 尾形 & 总郎 \\
\hline
\end{tabular}

\title{
A CASE OF PRIMARY HYPOURICOSURIC GOUT ASSOCIATED WITH MENTAL RETARDATION, SELF-MUTILATION AND SALT DEPENDENT HYPERTENSION
}

Koichi KawaI, MD, Toshiro Fujtra, MD, Mitsuo Itakura, MD, Satoshi Shimizu, MD, Yoshinobu Koide, MD, Nobuo KugaI, MD, Satoshi KImUra, MD, Kamejiro Yamashita, MD and Etsuro Ogata, MD Department of Internal Medicine, Institute of Clinical Medicine, The University of Tsukuba, Niihari-gun, Ibaraki-Ken

概要 15 才より痛風発作を発症, 高血圧症を合併し，ざに精神薄弱，自傷行為，無虹彩，高位口 蓋，停留等丸等の身体小奇形を伴う18才，男性患者において，その高尿酸血症の 原因を倹討した． hypoxanthine-guanine phosphoribosyltransferase活性扰よび尿酸排泄量は正常，尿酸クリアランスは著 しく低值，腎機能は軽度低下という結果と共に，特別な原疾患が考兄られないことから，原発性尿酸 排澌障害型痛風（括とらく尿酸分泌不全による）と診断した。をた，高血圧は食塩依存性の本態性高 血圧と判定された．以上より本例において高尿酸血症抢よび高血圧症の原因として，ともに尿細管の 機能障害が示唆された。

緒言

知能低下，自傷行為，不㭪薏運動を示す若年性 高尿酸血症はLesch-Nyhan症候群 として知られ, その高尿酸血症はhypoxanthine-guanine phosphoribosyltransferase (HGPRT) 欠損によることが明 らかになつて久しい゙。しかし，Lesch-Nyhan症 候群之同様に知能障害, 自傷行為, 不随意運動等 の症状を示すが，HGPRT活性が正常な 高尿酸血 症患者无報告されている ${ }^{23)}$. 我々は知能低下, 爪 を深くかむ等の自傷㑯向とともに各種の身体小奇 形，食塩依存性高血圧症を伴つた若年性痛風患者

[昭和54年9月25日受稿]

* 現 東京大学医学部第四内科
を経験し，その原因が原発性尿酸排泄不全にある と診断しえたので，これを報告するとともに，食 塩依存性高血圧症の原因亡尿細管に和ける尿排泄 不全との関係について考察を試みた。

\section{症例}

患者：18才，男.

主訴：高尿酸血症・高血生の精查。

家族歴： 母方両親に高血圧. 血族結婚および 瘦風患者はない。

発育歴・既往歴： 満期産 (2570 g)，仮死 状 態で出産. 体重増加覀く, 生後 4 力月目には近医 より脳性麻痺と診断されている. 不随意運動はな かつたが，首のすわり，歩行開始は打そく，知能 発達も不充分で特殊養護学級に入学. 13才頃より 
血が出る程に爪をかむようになり現在に至る。

現病歴： 昭和51年 3 月 (15才), 右足背に強 い疼痛を伴らび漫性発赤腫脹の発作，消炎剂投与 をうけ1週間程で治瘾.10月11月にも同様な発作。 昭和52年 1 月茨城県立中央病院に扎いて高尿酸 血症・高血王 $(156 / 106)$ ，蛋白尿を指摘され，以 降allopurinol - sulfinpyrazone, 降王薬 (reserpine, apresoline）を投与された．高尿酸血症・高血圧 はともにほぼ正常化していたが，昭和53年 2 月精 查のため当院に入院した.

入院時現症：身長 $152 \mathrm{~cm} ，$ 体重 $61.5 \mathrm{~kg}$ ，脈拍 62/分，整，血任186/98（左右差・上下肢差，異 常なし), 両眼無虹彩・両眼水晶体 混 濁・高位口 蓋・翼状頝・外反肘が認められた，両側停留等丸 (小指頭大のものが両巣径部に触れた)。腋毛は 全く見られなかつたが，陰毛はほぼ正常男性型で あつた，指の爪は極端に短かく，爪周囲に咬傷の 跡が認められた，知能低下 (IQ 60程度)，両眼 の水平眼振以外に神経学的異常所見はなく, また 痛風結節も認められなかつた．その他異常所見は なかつた。

表 1 . 入院時一般検查成結

\begin{tabular}{|c|c|c|c|}
\hline \multicolumn{2}{|l|}{ CBC } & UA & $3.1 \mathrm{mg} / \mathrm{dl}$ \\
\hline RBC & $460 \times 10^{4}$ & TG & $117 \mathrm{mg} / \mathrm{dl}$ \\
\hline $\mathrm{Hb}$ & $12.7 \mathrm{~g} / \mathrm{dl}$ & T.Chol & $169 \mathrm{mg} / \mathrm{dl}$ \\
\hline $\mathrm{Ht}$ & $38.7 \%$ & GOT & $15 \mathrm{U}$ \\
\hline WBC & 5200 & GPT & $8 \mathrm{U}$ \\
\hline Platelet & $22.1 \times 10^{4}$ & LDH & $383 \mathrm{U}$ \\
\hline \multicolumn{2}{|l|}{ Urinalysis } & alk-P-ase & $8.0 \mathrm{KA}-\mathrm{U}$ \\
\hline $\mathrm{pH}$ & 4.4 & Ch-E & $1.12 \Delta \mathrm{pH}$ \\
\hline Protein & $(-)$ & TTT & $5.4 \mathrm{U}$ \\
\hline Sugar & $(-)$ & $\mathrm{ZTT}$ & $8.0 \mathrm{U}$ \\
\hline Sediment & $\mathrm{np}$ & $\mathrm{Na}$ & $144 \mathrm{mEq} / \mathrm{l}$ \\
\hline \multicolumn{2}{|c|}{ Blood chemistry } & $\mathrm{K}$ & $4.9 \mathrm{mEq} / \mathrm{l}$ \\
\hline TP & $8.1 \mathrm{~g} / \mathrm{dl}$ & $\mathrm{Cl}$ & $105 \mathrm{mEq} / \mathrm{l}$ \\
\hline $\mathrm{Alb}$ & $64 \%$ & $\mathrm{Ca}$ & $4.8 \mathrm{mEq} / \mathrm{t}$ \\
\hline$\alpha_{1-\mathrm{gl}}$ & $2.1 \%$ & $\mathrm{P}$ & $2.7 \mathrm{mg} / \mathrm{dl}$ \\
\hline$\alpha_{2-\mathrm{gl}}$ & $7.4 \%$ & FBS & $87 \mathrm{mg} / \mathrm{dl}$ \\
\hline$\beta$-gl & $8.2 \%$ & ESR & $8 \mathrm{~mm}$ ( 1 時間値) \\
\hline$r$-gl & $18.4 \%$ & \multicolumn{2}{|c|}{ Serological studies } \\
\hline BUN & $20.5 \mathrm{mg} / \mathrm{dl}$ & GRP & $(-)$ \\
\hline \multirow[t]{2}{*}{ Creatinine } & $1.0 \mathrm{mg} / \mathrm{dl}$ & RA & $(-)$ \\
\hline & & ASO & $(-)$ \\
\hline
\end{tabular}

表2.内分泌学的检查成縝

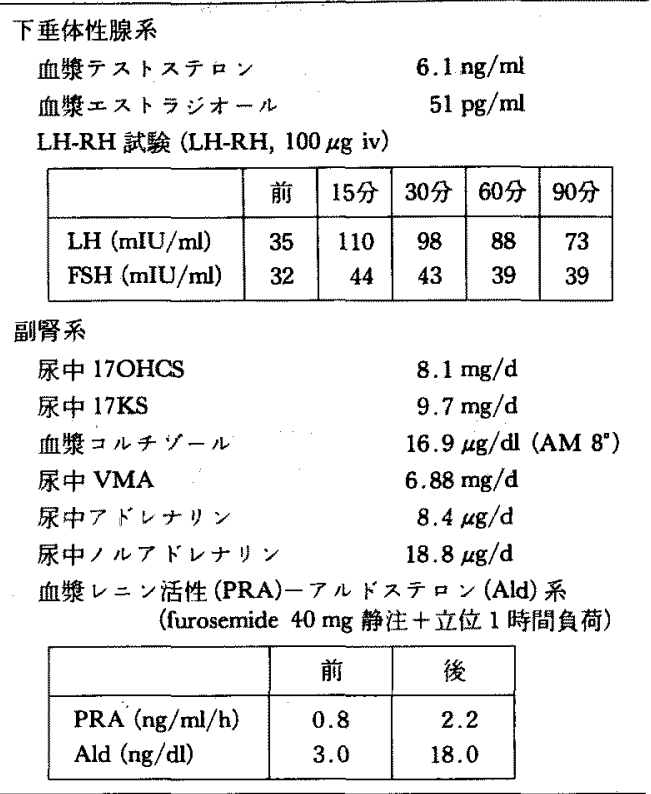

検查成績：入院時一般検查成績は表 1 のごと くで，尿のpH 4.4以外に大きな異常はみられなか つた。尿酸值はallopurinol - sulfinpyrazoneが投与 されていたため $3.1 \mathrm{mg} / \mathrm{dl}$ と低值を示した．眼底・ 心電図・胸部X線像に異常なく, 腎機能にはPSP は15分值 $22 \% ， 120$ 分合計 $74 \% ， 24$ 時間,クレアチ ニンクリアランスは $88.4 \mathrm{ml} / \mathrm{min}$ と軽度 の低下が 見られたＩVP・レノグラムには異常は認められ なかつた．内分泌機能検査結果は表 2 に示すごと くで，血浆テストステロン值は正常域にあつた が，LH-RH試験でLHの過大反応が認められ，粹 丸の発育不全は末梢性のものと判断された．その 他尿中17OHCS・17-KS・血䍝 コルチゾールレベ ルから，下垂体・副腎系の異常は認められなかつ た. 尿中カテュールフミン・VMA值・血浆 $レ=$ ン活性・血漿アルドステロン值は正常であつた.

尿酸代謝に関する検查（表 3，図 1)：尿酸 は酵素法で測定しだ)。図1に示すよらK, allopurinol, sulfinpyrazone投与時，血清尿酸值 - 尿酸 クリアランスとも正常域にあつたが，投与中止に

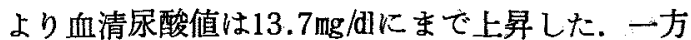




\section{表 3 ，尿酸代謝に関する检査}

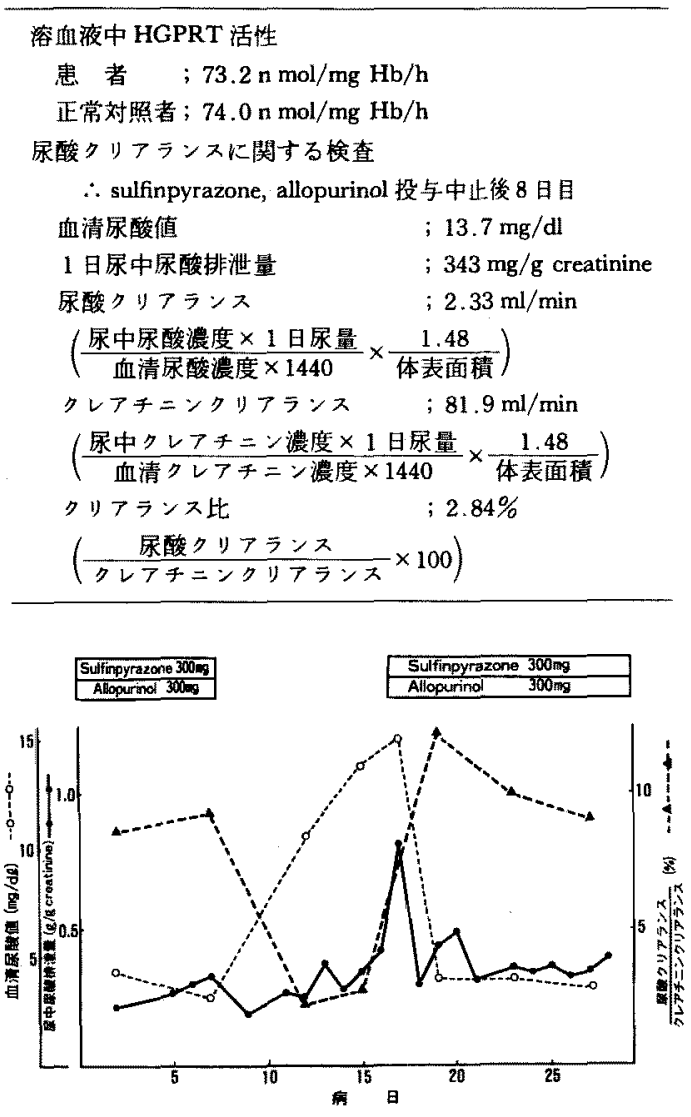

図 1.尿酸クリフランス

尿酸排泄量は増加せず，尿酸クリフランスは 2.33 $\mathrm{ml} / \mathrm{min}$, クレアチニンクリアランス比で $2.84 \%$ と 著しく低値であつた。これらの值を中村の報告ら にあてはめると，尿酸高度排泄低下型の高尿酸血 症に分類された．上記 2 種の薬物を再び使用する 之速やかに尿への尿酸排泄増加し，血清尿酸值 も正常化した. Johnsonらの方法 ${ }^{6}$ とょり測定し た赤血球溶血液中のHGPRT活性は正常域にあつ た、尿は酸性尿であつたが，血液ガス分析ではpH $7.36 \cdot \mathrm{HCO}_{3}{ }^{-} 26.2 \mathrm{mEq} / l$ と特に代謝性アシドー シスを示す所見はなかつた。

入院後，降圧薬投与をせず 1 日・10 g の塩分制 限を行なつたところ，血圧は約 7 日の経過で140/ 86に低下した。亦た既に述べたように腎機能・内
分泌機能検查所見等に特別な異常が認められな いことから，本例は食塩依存性本態性高血圧の病 態にあるものと理解された。な拈，染色体検査は 46XYであつた.

\section{考 案}

本患者は高尿酸血症に知能低下・自傷行為・各 種身体小奇形を合併し，Lesch-Nyhan症候群が薙 われ入院した。しか Lallopurinol, sulfinpyrazone を中止した時，腎機能はほぼ正常に保たれている にもかかわらず尿酸クリアランスは非常に低く， 尿酸排泄絶対值もやや低いこと，HGPRT活性は 正常なこと，尿酸排泄を障害するよらな一義的原 因が見い出されなかつたことから，原発性尿酸排 泄障害型の痛風と診断された，HGPRTについて は近年，至適条件で測定した場合には正常でも， km等の異常によりin vivoでは活性の低下が如ら れる例も報告されている7。しかしながら，それ らはいずれも尿酸過剩産生型であり，本例ではこ の問題についての精查は行なわなかつた.

痛風の原因として，尿酸の過剩産生がまず疑 われるが，尿酸の排泄障害に上る痛風もあるこ とが, Nugent and Tyler" ${ }^{8)}$. Seegmiller et al ${ }^{9)}$.

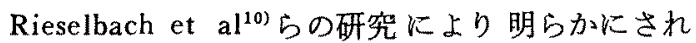
てきた，我国でも上田泰ら ${ }^{11}$ は自験例痛風患者の 原因をしらべ，その約 $20 \%$ 疥酸排泄障害による と報告している。すなわち，血中尿酸プールの $2 / 3$ 〜3/4が 1 日尿中に 排泄されるが，尿酸は糸球体 から完全に沪過されたのち，そのほとんどが近位 尿細管で再吸収され，遠位尿細管で分泌される部 分（沪過された 5〜10\%）が尿に排泄されるとさ れている ${ }^{12)}$. Steele et $\mathrm{al}^{133}$ 惊尿細管に叔ける尿 酸再吸収分泌機構は Ccrが $15 \mathrm{ml} / \mathrm{min}$ 以上の患者で は正常に保たれており，Ccrが15ml/min以下では じめて血中尿酸值の上昇をきたすと述べている。 本症例に和いては腎機能の軽度低下 (Ccr 88.4 $\mathrm{ml} / \mathrm{min})$ が見られるが，これが尿酸排泄障害の 根本的原因とは考元難い、またサイアサイド系利 尿薬等の薬物投与時や乳酸・ケトン体等の体内蓄 積によるアシドーシスのときにも尿酸分泌は抑制 
されることが知られているが本例ではそのような 所見は得られていない。

若年期発病の痛風はきわめて希であり，Treadwell ${ }^{4)}$ の文献的考察によると，1970年までに66例 の報告をみるに過ぎず，その男女比は $2 ： 1$ であ る。すなわち，成人にみられる痛風とくらべ明ら かに女性の比率が高いことが分かる.また，過 去に報告された原因の明らかな若年者の高尿酸血 症ないし痛風 の多くは, HGPRT活性低下による ものである. HGPRT正常で精神薄弱・自閉的性 格・無疶症を伴ら高尿酸血症の場合 ${ }^{15)}$ 飞を尿酸の 合成六進が証明されているし，既述の文献2)3)の 症例，さらには運動失調・腤を伴つた家族例の場 合 ${ }^{16)}$ 尿酸クリアランスの低下は明らかではな く, 本例のごとさ原発性尿酸分泌低下型のものが 15才といら若年者でかつ男性とはいえ，その性ホ ルモンレベルが低い患者に発症した例は非常に希 なことと思われる. 本例は精神薄弱・自傷行為と いつたLesch-Nyhan症候群的所見のほかK，各種 の身体小奇形を伴つて和り，この尿酸排泄障害も 何らかの遗伝子異常に上る可能性を考兄, 染色体 分析を行なつたが異常は諗められなかつた．本例 の自傷行為は血中尿酸值を正常化することにより 軽快したようにも見えたが，高尿酸血症と自傷行 為との関係については未だ明らかでない。

次に本例は高血圧を合併しているが，既述の如 く二次性高血圧の所見はみられなかつた。 しか し，食塩依存性が見られることから，この本態性 高血圧の原因が何らかのNa再吸収機構の異常と 関保していることも予想され，尿酸分泌不全と併 せ興味あるところである，従来，痛風に高血圧の 合併が高いことは周知のことであり，その原因と して，高血圧患者では血中乳酸值が高いことが示 され，それにより尿酸分泌障害が生ずるといら報 告7も西る。しかし本例は, 特に代謝性アシドー シスの所見はなく，むしろ尿細管障害による尿 酸・Naの貯留といら観点から両者をとら光らる 可能性を示唆している.すなわち，近位尿細管に 技ける尿酸の再吸收がNaのactive transportに依存
していることは明らかにされつつあるが，最近 Holmes et $\mathrm{al}^{18)}$ は尿酸クリアランスの低下してい る原発性痛風患者において，Naの再吸收が充進 状態にあることを認め，尿酸排泄障害に伴つた Naの排溫の低下が高血圧を合併しやすくしてい る原因ではないかと述べている。 また原発性排泄 障害型の痛風患者では,グリシン等のアミノ酸ク リアランスる低下しているとの報告197ああり，本 症例も何らかの尿細管機能障害のため $\mathrm{Na}$ と尿酸 の排泄が低下し，尿酸排泄障害型痛風之食塩依存 性本態性高血圧を同時に生じたのではないかと考 えている.

\section{結 語}

15才より痛風発作が生じた知能低下・自傷行 為・無虹彩等の各種小奇形扣よび食塩依存性本態 性高血圧を伴う患者の高尿酸血症の原因を精査し た．原因として，尿酸分泌障害による尿酸排泄障 害が考兄られた。この事実より，本患者において 痛風之食塩依存性本態性高血圧症が合併した機序 について考察を試みた。

本原稿の準備中に, 自䈓行為, チェック様不随 意運動, 等の神経症状を有し主として男子が羅患 することが知られているGilles de la Tourette症 候群で, 赤血球溶血液中HGPRT活性レベルが正 常であるにすかかわらず，この酵素が正常醭素よ り不安定で生化学的に異なることが報告された (Van Woert MH, et al: New Eng J Med 296: 210, 1977, Johnson GG, et al: New Eng J Med 297: 339，1977). 本患者のHGPRT特よび薬物に対す る腎尿酸排泄動態，L-5-hydroxytryptophanによる 自傷行為の治療については，現在愉討中である.

謝辞 最後に，染色体分析をしていたたいた本学基碟 医学系・近藤郁子先生に深謝致します。

\section{文 献}

1) Lesch M and Nyhan WN: A familial disorder of uric acid metabolism and central nervous system function. Amer J Med 36: 561, 1964.

2) Benke PJ, et al: Azaguanine-resistance as a manifestation of a new form fo metabolic overproduction of uric acid. Amer J Med 
$52: 547,1972$

3) Etienne JC, et al: Hyperuricosuric encephalopathy with self-mutilation. Rev Rhum Mal Osteoartic 40: 265, 1973.

4) Gochman N and Schmitz JM: Automated determination of uric acid, with use of a uricase-peroxidase system. Clin Chem 17: $1159,1971$.

5) 中村徹：痛風の高尿酸血症における尿酸代 謝動態。最新医学 $29: 430,1974$.

6) Johnson RB, et al: Hypoxanthine-guanine phosphoribosyltranferase: A simple spectrophotometric assay. Clin Chim Acta 80: 203, 1977.

7) Mcponald TA and Kelley WN: Lesch-Nyhan syndrome altered kinetic properties of mutant emzyme. Science 171: 689, 1971.

8) Nugent CA and Tyler FH: The renal excretion of uric acid in patients with gout and in nongouty subjects. I Clin Invest 38: 1890, 1959.

9) Seegmiller JE, et al: The renal excretion of uric acid in gout. J Clin Invest $41: 1094,1962$.

10) Rieselbach RE, et al; Diminished renal urate secretion per nephron as a basis for primary gout. Ann Intern Med 73: 359, 1970.
11）上田泰, 他：痡風に上㹂障害. 内科 27 : $216,1971$.

12）尾形悦郎，板倉光夫：堅の尿酸排泄と之の調 節、新内科学大系 $46 \mathrm{~A}$ 代謝異常 II a. 鎮目和 夫, 他編. 中山書店, 東京, $1979, \mathrm{p} 32$.

13) Steele TH and Rieselbach RE: The contribution of residual nephrons within the chronically diseased kidney to urate homeostatis in man. Amer J Med 43: 876, 1967.

14) Treadwel BLJ: Juvenile gout. Ann Rheum Dis 30: 279, 1971.

15) Nyhan WL, et al: A new disorder of purine metabolism with behaviorial manifestations. J Pediatr 74: 20, 1969.

16) Rosenberg A, et al: Hyperuricemia and neurologic deficits, A family siudy. New Engl J Med 282: 992, 1970.

17) Cannon PJ, et al: Hyperuricemia in primary and renal hypertension. New Engl J Med 275: 457, 1966.

18) Holmes EW, et al: The kidney and uric acid excretion in man. Kidney Inter 2: 115, 1972.

19) Kaplan D, et al: Amino acid excretion in primary hyperuricemia. Ann Rheum Dis 28: 180, 1969. 